\title{
Isolation and Characterization of a New Gram-Negative, Acetone-Degrading, Nitrate-Reducing Bacterium from Soil, Paracoccus solventivorans sp. nov.
}

\author{
HUBERT SILLER, ${ }^{1}$ FRED A. RAINEY, ${ }^{2}$ ERKO STACKEBRANDT, ${ }^{2}$ AND JOSEF WINTER ${ }^{1 *}$ \\ Institut für Ingenieurbiologie und Biotechnologie des Abwassers, Universität Karlsruhe, 76128 Karlsruhe, ${ }^{1}$ and \\ Deutsche Sammlung von Mikroorganismen und Zellkulturen GmbH, 38124 Braunschweig, ${ }^{2}$ Germany
}

\begin{abstract}
An acetone-degrading, nitrate-reducing, coccoid to rod-shaped bacterium, strain L1, was isolated from soil on the site of a natural gas company. Cells of the logarithmic growth phase reacted gram positive, while those of the stationary growth phase were gram negative. Single organisms were 0.4 to 0.5 by 0.9 to $1.5 \mu \mathrm{m}$ in size, nonmotile, and non-spore forming and had poly- $\beta$-hydroxybutyrate inclusions. The doubling time of strain $\mathrm{L1}$ on acetone- $\mathrm{CO}_{2}$-nitrate at the optimal pH of 7 to 8 and the optimal temperature of 30 to $37^{\circ} \mathrm{C}$ was $12 \mathrm{~h}$. More than $0.2 \% \mathrm{NaCl}$ or $10 \mathrm{mM}$ thiosulfate inhibited growth. For oxygen or nitrate respiration, acetone and a few organic chemicals were utilized as carbon sources whereas many others could not be used (for details, see Results). Bicarbonate (or $\mathrm{CO}_{2}$ ) was essential for growth on acetone but not for growth on acetoacetate. The growth yields for acetone- $\mathrm{CO}_{2}$ and acetoacetate were 28.3 and $27.3 \mathrm{~g} / \mathrm{mol}$, respectively. With acetone as the carbon source, poly- $\beta$-hydroxybutyrate accounted for up to $40 \%$ of the cellular dry weight. The DNA of strain L1 had a G+C content of $68.5 \mathrm{~mol} \%$ (as determined by high-performance liquid chromatography of nucleotides) or $70 \mathrm{~mol} \%$ (as determined by the $T_{M}$ method). The sequence of the gene coding for the 16S rRNA led to the classification of strain L1 in the paracoccus group of the alpha subclass of the Proteobacteria. The new isolate is named Paracoccus solventivorans sp. nov. DSM 6637.
\end{abstract}

Acetone is a fermentation product of fungi (15), clostridia (see, for example, reference 43 ), and several other bacteria (6, $35,36,51,57,58)$. It is also excreted into the environment in ripening apples as a bioconversion product derived from pyruvate. Commercially, acetone is produced from isopropanol, cumene, or propane to serve as a solvent for resins, fats, oil, plastics, waxes, etc. (30). Acetone may therefore occur in many ecosystems as a naturally produced substance or as an industrial pollutant. It is, however, not accumulating because of its degradability by aerobic (see, e.g., references 25 and 27) and anaerobic (see, e.g., references 28,36 , and 38 ) bacteria. Because of its biological degradability in the presence or absence of oxygen, it is an especially suitable, nontoxic elutant for extraction of polycyclic aromatic hydrocarbons (PAHs) from contaminated soil for bioremediation. After extraction, the acetone-PAH solution can be easily separated by evaporation or distillation of the solvent. The acetone residue in the soil is harmless because of its rapid biological degradation. In an attempt to study PAH degradation in contaminated soil samples, PAHs were extracted with acetone. In the first enrichments, nitrate-reducing, acetone-degrading bacteria were obtained. From these enrichments, a new acetone-degrading organism, strain L1, was isolated and subsequently characterized in detail.

\section{MATERIALS AND METHODS}

Sources of organisms. Strain L1 was isolated from a soil sample taken at a depth of $1 \mathrm{~m}$ at the site of a defunct natural gas company. Thiosphaera pantotropha DSM 2510 (syn. Paracoccus denitrificans [26]), Pseudomonas delafieldii DSM 64, and Lactobacillus plantarum DSM 20174 were obtained from Deutsche Sammlung von Mikroorganismen und Zellkulturen GmbH, Braunschweig, Federal Republic of Germany.

Media and culture conditions. The medium for enrichment, isolation, and

* Corresponding author. Mailing address: Institut für Ingenieurbiologie und Biotechnologie des Abwassers, Universität Karlsruhe, Am Fasanengarten, 76128 Karlsruhe, Germany. Phone: 721/608-2297. Fax: 721/694826. Electronic mail address: gil3Qrz.uni-karlsruhe.de. cultivation of strain $\mathrm{L} 1$ contained (per liter) $\mathrm{Na}_{2} \mathrm{HPO}_{4}, 0.95 \mathrm{~g} ; \mathrm{KH}_{2} \mathrm{PO}_{4}, 0.45 \mathrm{~g}$; $\mathrm{NH}_{4} \mathrm{Cl}, 0.6 \mathrm{~g} ; \mathrm{MgCl}_{2} \cdot 6 \mathrm{H}_{2} \mathrm{O}, 0.06 \mathrm{~g} ; \mathrm{CaCl}_{2} \cdot 2 \mathrm{H}_{2} \mathrm{O}, 0.06 \mathrm{~g} ; \mathrm{NaHCO}_{3}, 4 \mathrm{~g}$; vitamin solution (56), $10 \mathrm{ml}$; trace mineral solution SL10 (53), $1 \mathrm{ml}$; sodium nitrate, 40 $\mathrm{mmol}$; and acetone, $10 \mathrm{mmol}$. For the anaerobic cultivation experiments, nitrate was omitted from the medium and yeast extract (Merck no. 3753; 0.1 g/liter), a selenite-tungstate solution $(47)(0.5 \mathrm{ml} / \mathrm{liter})$, resazurin $(0.1 \%$ [wt/vol], $0.1 \mathrm{ml} /$ liter $)$, and $\mathrm{Na}_{2} \mathrm{~S} \cdot 7-9 \mathrm{H}_{2} \mathrm{O}(0.12 \mathrm{~g} /$ liter $)$ were added. The $\mathrm{pH}$ of the medium was adjusted to 7 with $1 \mathrm{~N} \mathrm{NaOH}$ before autoclaving. To determine the $\mathrm{CO}_{2}$ requirement of strain L1, a phosphate-buffered mineral medium was used. It contained (per liter) $\mathrm{K}_{2} \mathrm{HPO}_{4}, 1.4 \mathrm{~g} ; \mathrm{KH}_{2} \mathrm{PO}_{4}, 0.45 \mathrm{~g} ; \mathrm{MgCl}_{2} \cdot 6 \mathrm{H}_{2} \mathrm{O}, 0.1 \mathrm{~g}$; $\mathrm{CaCl}_{2} \cdot 2 \mathrm{H}_{2} \mathrm{O}, 0.04 \mathrm{~g} ; \mathrm{NH}_{4} \mathrm{Cl}, 0.6 \mathrm{~g} ; \mathrm{FeSO}_{4} \cdot 2 \mathrm{H}_{2} \mathrm{O}, 0.01 \mathrm{~g} ; \mathrm{NiCl}_{2}(0.2 \%$ [wt/vol]), $0.5 \mathrm{ml}$; vitamin solution (56), $10 \mathrm{ml}$; and trace mineral solution SL10 (53), $1 \mathrm{ml}$. Acetone and sodium nitrate (10 and $40 \mathrm{mM}$ final concentration, respectively) or other substrates and electron acceptors were added from sterile stock solutions. Medium for petri dishes was solidified by addition of $20 \mathrm{~g}$ of agar per liter. $T$. pantotropha was cultured in medium 356 of the Deutsche Sammlung von Mikroorganismen und Zellkulturen $\mathrm{GmbH}(9 \mathrm{a})$.

For anaerobic or anoxic growth experiments, media were prepared as described by Balch et al. (2) and dispensed in an anaerobic chamber (Coy Laboratory Products Inc., Ann Arbor, Mich.) in 10- to 500-ml portions into 120-ml serum bottles or 1-liter flasks (Schott, Mainz, Germany). The serum bottles or flasks were sealed with butyl rubber stoppers and with aluminum crimps or screw caps, respectively. A gas phase of $\mathrm{N}_{2}-\mathrm{CO}_{2}\left(80: 20\right.$ [vol/vol]) or $\mathrm{N}_{2}(100 \%)$ at a pressure of $300 \mathrm{kPa}$ was then introduced (2). Media were autoclaved, inoculated by using syringes, and incubated at $33^{\circ} \mathrm{C}$ on rotatory shakers at $100 \mathrm{rpm}$. The formation of spores was tested in accordance with the procedure of Winter et al. (54).

Microscopy of cell suspensions and stained cells. Photomicrographs of suspensions of strain L1, fixed in accordance with the procedure of Pfennig and Wagener (34), were taken at a magnification of $\times 1,250$ with a Zeiss Standard 14 fluorescence phase-contrast microscope and a Minolta camera. The scanning electron micrograph was taken with a DSM 950 scanning electron microscope (Zeiss, Oberkochen, Germany) at an accelerating voltage of $10 \mathrm{kV}$. Electron photomicrographs of thin sections of strain L1 cells were taken in accordance with the procedure of Kretzer and Andreesen (22).

Poly- $\beta$-hydroxybutyrate (PHB) inclusions of cells were stained with Sudan black B (12) or Nile blue A (33) and viewed by bright-field or fluorescence microscopy, respectively. Gram staining was performed by the procedure of Drews (12) with Pseudomonas delafieldii and L. plantarum as controls.

Phylogenetic relatedness of strain L1. Genomic-DNA extraction, PCR amplification of the gene coding for the 16S rRNA (16S rDNA), and purification of PCR products were carried out as described previously $(39,40)$.

Purified PCR products were sequenced with the Taq Dye-Deoxy Terminator Sequencing Kit (Applied Biosystems, Hercules, Calif.) as directed in the manufacturer's protocol. Sequencing reaction products were electrophoresed with the Applied Biosystems 373A DNA sequencer. The 16S rDNA sequence was man- 
ually aligned against representative sequences of members of the alpha proteobacterial line of descent. Pairwise evolutionary distances were computed by using the correction of Jukes and Cantor (19). The least-squares distance method of De Soete (9) was used in the construction of the phylogenetic dendrogram from distance matrices. The ribosomal database of Maidak et al. (29) was used to obtain reference $16 \mathrm{~S}$ rDNA sequences.

Isolation of DNA for determination of the moles percent $G+C$ and DNA-DNA similarity. DNA was isolated and the $\mathrm{G}+\mathrm{C}$ content determined as described by Marmur and Doty (30) and Zellner et al. (57). DNA-DNA hybridization was carried out after labelling of DNA (21) with a nick translation system (U1001) from Boehringer GmbH (Mannheim, Germany) using the filter binding technique $(4,14)$.

Growth measurement and growth yield. The optical densities of cultures were determined in cuvettes $(1$ by $1 \mathrm{~cm}$ ) with a Gilford Stasar II photometer at 578 $\mathrm{nm}$. For analysis of the growth yield, acetone utilization and cell yield in $200 \mathrm{ml}$ of medium were determined. Cells were harvested by centrifugation, washed once with tap water, dried at $105^{\circ} \mathrm{C}$, and weighed. The PHB content of cells was quantified after conversion to crotonic acid and separation by high-performance liquid chromatography (HPLC) (see below). To relate optical densities and cell mass of strain L1, a calibration curve was prepared for growth on acetone- $\mathrm{CO}_{2}$ nitrate at optical densities (ODs) of $0.4,0.9$, and 1.2 .

Analytical methods. PHB was extracted from cells by the method of Doi et al. (11) and converted to crotonic acid as described by Law and Slepecky (24) Crotonic acid was quantified by HPLC on a Polypore H column ( $4.6 \mathrm{~mm}$ by 250 $\mathrm{mm}$; Brownlee, Kontron, Eching, Germany) in accordance with the procedure of Karr et al. (20). Acetoacetate was determined by the method of Walker (49). Volatile fatty acids, alcohols, and ketones $(2-\mu l$ injections) were analyzed with a Packard model 433 gas chromatograph equipped with a Tefion column ( $2 \mathrm{~m}$ by $1.5 \mathrm{~mm}$ ) packed with Chromosorb C 101 (80/100 mesh; Sigma, Munich, Germany) at an oven temperature of $170^{\circ} \mathrm{C}$ (for fatty acids) or $120^{\circ} \mathrm{C}$ (for alcohols or ketones). The injector and detector were heated to $210^{\circ} \mathrm{C} . \mathrm{H}_{2}, \mathrm{CO}_{2}$ (carrier gas, nitrogen), and $\mathrm{N}_{2}$ (carrier gas, argon) were determined by gas chromatography as described previously (55).

Sulfate, nitrate, and nitrite were determined with Spectroquant test kits 14791 and 14773 (Merck, Darmstadt, Germany), respectively. Alternatively, nitrate was determined by the method described in the Deutsche Einheitsverfahren zur Wasser-, Abwasser- und Schlammuntersuchung (13).

${ }^{14} \mathrm{C}$ radioactivity of substrates and products was determined in Bray's scintillation cocktail (8) with a Kontron liquid scintillation counter (Brother M-1109). When acetone in cultures supplemented with $\left[2-{ }^{14} \mathrm{C}\right]$ acetone- $\mathrm{CO}_{2}$ or acetone${ }^{14} \mathrm{CO}_{2}$ was almost depleted, $0.1 \mathrm{ml}$ of ice-cooled sample was acidified with $0.1 \mathrm{ml}$ of $2 \mathrm{~N} \mathrm{HCl}$ and centrifuged at $4^{\circ} \mathrm{C}$. Radioactivity in the supernatant was considered to be due to residual acetone, acetoacetate, or an unidentified compound, since no other products could be detected by gas chromatography-HPLC

${ }^{14} \mathrm{CO}_{2}$ from $\left[2-{ }^{14} \mathrm{C}\right.$ acetone was slowly stripped with $\mathrm{N}_{2}$ after acidification of the culture liquid and absorbed in two traps, in sequence, containing $3 \mathrm{~N} \mathrm{KOH} .{ }^{14} \mathrm{C}$ radioactivity in cells was determined after separating the cells by centrifugation, washing the cells twice with sterile medium, and resuspending them in Bray's scintillation cocktail. Radiolabelled PHB in cells was extracted with chloroform by the method of Anderson and Dawes (1). The dried cell pellet from $10 \mathrm{ml}$ of culture suspension was incubated with $1 \mathrm{ml}$ of chloroform for $24 \mathrm{~h}$. After evaporation of the chloroform to a final volume of $0.2 \mathrm{ml}, 1 \mathrm{ml}$ of ethanol was added to precipitate the PHB. The precipitate was collected by filtration on nitrocellulose filters ( $0.45-\mu \mathrm{m}$ pore size; Sartorius, Göttingen, Germany). The PHB on the dried filter was counted directly in Bray's scintillation cocktail. ${ }^{14} \mathrm{C}$-labelled acetoacetate and an unidentified intermediate in spent medium, formed from ${ }^{14} \mathrm{C}$-labelled acetone or $\left[{ }^{14} \mathrm{C}\right]$ bicarbonate, were analyzed by HPLC. Bacteria in the spent medium were removed by centrifugation. Then the supernatant was acidified with $\mathrm{H}_{2} \mathrm{SO}_{4}$ and concentrated 10 -fold by evaporation, and $20 \mu \mathrm{l}$ was applied to a Polypore $\mathrm{H}$ column (Brownlee; Kontron). Substances eluting with 10 $\mathrm{mM} \mathrm{H}_{2} \mathrm{SO}_{4}$ (flow rate, $0.15 \mathrm{ml} / \mathrm{min}$ ) were detected with a UV detector at $263 \mathrm{~nm}$. The radioactivity of collected peak fractions was counted in Bray's scintillation liquid (8).

Protein patterns of cytoplasm, cell wall components, and enzyme activities. Cells ( $1 \mathrm{~g}$ [wet weight]) in $100 \mathrm{mM}$ Tris- $\mathrm{HCl}$ buffer, $\mathrm{pH} 8.6$, were broken by two passages through a French pressure cell (Aminco, Silver Spring, Md.) at $10^{8} \mathrm{~Pa}$. Cell walls were pelleted by centrifugation, and the protein content in the clear cytoplasmic solution was determined (7). Ten micrograms of protein in buffer (23) was separated by electrophoresis in 5 to $25 \%$ logarithmic sodium dodecyl sulfate (SDS)-polyacrylamide gels (31), and gels were stained with silver nitrate (17). Cell walls were hydrolyzed in $6 \mathrm{~N} \mathrm{HCl}$ at $100^{\circ} \mathrm{C}$ for $16 \mathrm{~h}$, residual $\mathrm{HCl}$ was evaporated, and the hydrolysate was resolubilized in water. An $m$-diaminopimelic acid (DAP) standard and the cell wall hydrolysates were subjected to silica gel thin-layer chromatography (41) and stained with ninhydrin.

Activities of oxidoreductases were assayed in crude cell extracts in accordance with the procedure of Bergmeyer (3). Thiolase and succinyl coenzyme A $(\mathrm{CoA})$ : acetoacetate CoA transferase were assayed by the method of Stern (45), and malate synthase and isocitrate lyase were determined by the method of Dixon and Kornberg (10).

Chemicals. All chemicals and solvents were purchased from Aldrich (Steinheim, Germany), Merck, Serva (Heidelberg, Germany), or Sigma. Enzymes, coenzymes, and biochemical reagents were from Boehringer, Sigma, or Serva.
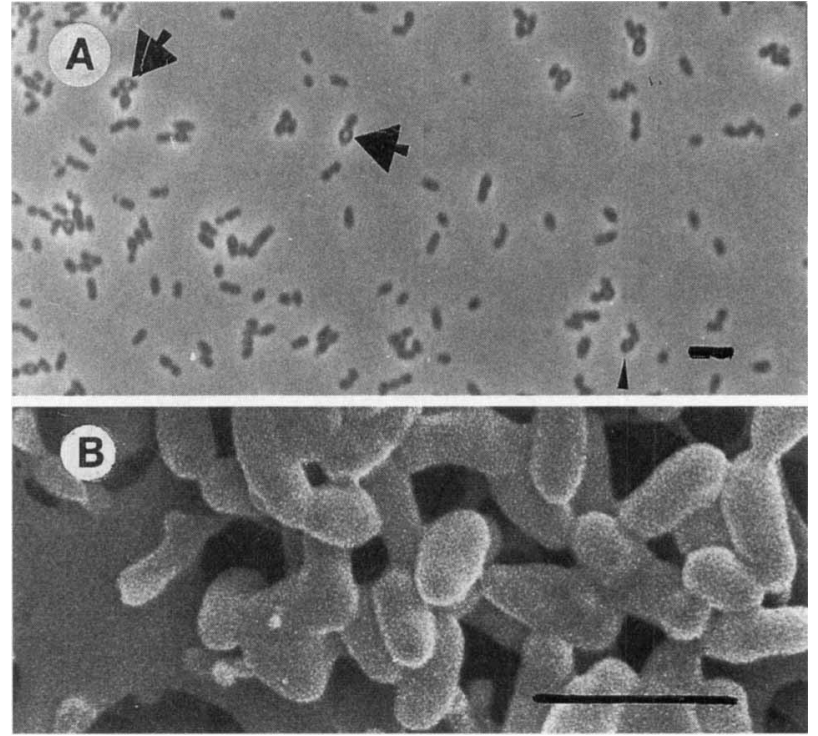

FIG. 1. Phase-contrast (A) and scanning electron (B) photomicrographs of strain $\mathrm{L} 1$ cells after growth on acetone plus nitrate in the presence of $\mathrm{N}_{2}-\mathrm{CO}_{2}$. Arrows point to cells with PHB inclusions. Bars, $2 \mu \mathrm{m}$.

Radiochemicals were obtained from Sigma (Munich, Germany) and NEN (Dreieich, Germany). The specific activities of the $\left[2-{ }^{14} \mathrm{C}\right]$ acetone and $\mathrm{NaH}^{14} \mathrm{CO}_{3}$ were 2.8 and $6.8 \mathrm{mCi} / \mathrm{mmol}$, respectively.

\section{RESULTS}

Isolation of strain $\mathrm{L1}$ and its morphology and cell constituents. Soil samples were inoculated into medium containing 10 $\mathrm{mM}$ acetone and $40 \mathrm{mM}$ nitrate. After 1 to 2 weeks, growth occurred, and aliquots were subcultured twice before the cultures were plated on agar medium. Round colonies $1 \mathrm{~mm}$ in diameter were obtained after 3 weeks of anoxic incubation. Single colonies were inoculated into an acetone- $\mathrm{CO}_{2}$-nitrate broth medium. The cultures were plated once again, and a subculture from a single colony was further characterized as strain L1.

Strain L1 formed short rods 0.4 to 0.5 by 0.9 to $1.5 \mu \mathrm{m}$ in size (Fig. 1). It consisted mainly of single coccoid cells and doublets, and occasionally there were chains of up to five bacteria. Strain L1 was nonmotile, did not form spores, and had positive catalase and oxidase reactions. When viewed under the phasecontrast microscope, many cells had bright inclusions (Fig. 1A, arrows). These inclusions consisted of PHB, as judged from their staining with Sudan black B or Nile blue A. Strain L1 was gram variable, staining gram positive in the logarithmic growth phase and gram negative in the stationary growth phase. The cell walls did not contain DAP, the typical diamino acid of gram-negative cell walls, and cells were lysed with $5 \mathrm{mg}$ of lysozyme per ml within $4 \mathrm{~h}$ at room temperature. No lysis occurred with SDS $(10 \mathrm{mg} / \mathrm{ml}), \mathrm{NaOH}, \mathrm{HCl}$, or $\mathrm{H}_{2} \mathrm{SO}_{4}(10 \%$ [vol/vol] each) under the same conditions. For comparison, the gram-negative bacterium T. pantotropha (syn. Paracoccus denitrificans [26]), whose cell walls also lack DAP, also stained gram positive during the logarithmic growth phase. Thin sections of strain L1 revealed the typical gram-negative cell wall structure, with an outer membrane and a very thin murein layer (Fig. 2).

Optimal conditions for growth on acetone- $\mathrm{CO}_{2}$-nitrate. With acetone, strain L1 grew optimally between 30 and $37^{\circ} \mathrm{C}$ and at a $\mathrm{pH}$ of 7 to 8 . Growth was inhibited by $0.2 \% \mathrm{NaCl}$, and 


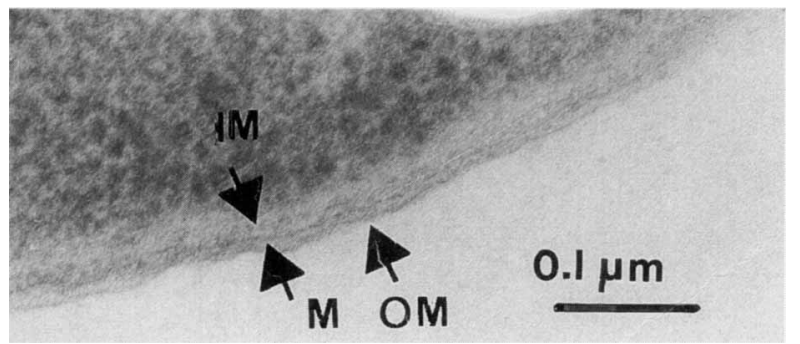

FIG. 2. Sector of a thin section of a cell of strain L1, showing the cell wall architecture. IM, cytoplasmic membrane; M, murein; OM, outer membrane.

no growth was observed with $2 \% \mathrm{NaCl}$. Addition of 5 to $10 \mathrm{mM}$ thiosulfate slightly enhanced growth (the same final OD was reached after $80 \mathrm{~h}$ instead of $100 \mathrm{~h}$ ), whereas $20 \mathrm{mM}$ thiosulfate was strongly inhibitory. Whether this was due to the thiosulfate itself or sulfite contamination of the thiosulfate was not tested. Omission of vitamins from the standard medium did not affect the growth of strain L1. Omission of bicarbonate from the medium and $\mathrm{CO}_{2}$ from the headspace completely prevented growth with acetone as the carbon source and nitrate as the electron acceptor.

Carbon and inorganic electron sources. No autotrophic growth of strain L1 was obtained with $\mathrm{H}_{2}-\mathrm{CO}_{2}$ or $\mathrm{H}_{2} \mathrm{~S}-\mathrm{CO}_{2}$ with or without nitrate. Under anoxic conditions in the presence of nitrate, growth occurred with the following carbon sources (final OD in parentheses): acetone (1.15), 2-butanone $(0.8)$, fumarate $(0.75)$, gluconate $(0.75)$, ribose $(0.2)$, pyruvate (0.8), Casamino Acids (0.7), 2-propanol (0.64), n-butanol (0.16), $\alpha$-ketoglutarate $(0.63)$, 3-hydroxybutyrate $(1.1)$, succinate $(0.52)$, propionate $(0.4), n$-butyrate $(0.7)$, acetoacetate $(1.0)$, glycine $(0.12)$, isoleucine $(0.38)$, aspartate $(0.45)$, asparagine $(0.24)$, and glutamate $(0.57)$. If no carbon source was added, an OD of 0.05 was reached.

In the presence of air, Casamino Acids (0.6), yeast extract $(0.5)$, gluconate $(0.3)$, glutamate $(0.15)$, acetone $(0.75)$, and acetate $(0.1)$ were utilized (OD without a carbon source, 0.05 ).

The following substances were not used as carbon sources for nitrate respiration: alanine, valine, histidine, leucine, threonine, cysteine, methionine, phenylalanine, tyrosine, tryptophan, glutamine, lysine, arginine, ornithine, proline, fructose, glycogen, glycerol, lactate, malate, citrate, mannose, arabinose, xylose, maltose, sucrose, lactose, mannitol, sorbitol, inositol, glucose, galactose, cellobiose, tartrate, cyclohexanol, $n$-butanol, ethanol, methanol, formate, benzoate, 4-aminobenzoate, 4-hydroxybenzoate, DL-mandelic acid, pimelate, cyclopenanone, 3-pentanone, methylamine, dimethylamine, trimethylamine, tetramethylamine, and 2,5-hexadione. With the exception of the last 11 , which were not tested for oxygen respiration, these substrates were found to be unused as carbon sources in that process.

Under nitrate-reducing growth conditions, the doubling time was $8.5 \mathrm{~h}$ with 3 -hydroxybutyrate, $9.1 \mathrm{~h}$ with acetoacetate, $12 \mathrm{~h}$ with acetone, and $117 \mathrm{~h}$ with 2-propanol as the carbon source. The molar growth yield was 27.3 and $28.3 \mathrm{~g} / \mathrm{mol}$ with acetoacetate and acetone- $\mathrm{CO}_{2}$ as the carbon source, respectively, and nitrate as the electron acceptor. Nitrate, but not nitrite, sulfate, or fumarate, could be used as an electron acceptor during growth on acetone plus $\mathrm{CO}_{2}$.

Efficiency of growth, kinetics of acetone-nitrate utilization, and carbon dioxide requirement. The growth response of strain $\mathrm{L} 1$ on acetone- $\mathrm{CO}_{2}$ plus nitrate medium is shown in Fig. 3 . The acetone-to-nitrate consumption stoichiometry was approximately 1:2. The PHB content of cells increased with

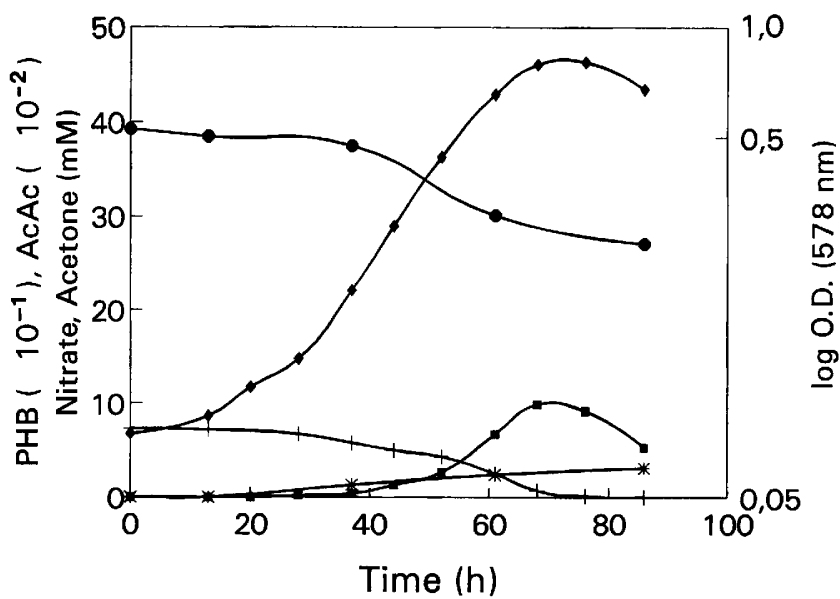

FIG. 3. Kinetics of acetone and nitrate utilization. The medium was supplemented with $10 \mathrm{mM}$ acetone and $40 \mathrm{mM}$ nitrate, inoculated with a log-phase culture to $5 \%$, and incubated at $30^{\circ} \mathrm{C}$. Symbols: + , acetone; $\bullet$, nitrate; $\bullet, \mathrm{OD}_{578}$; 口, PHB; *, acetoacetate (AcAc).

growth and contributed up to $40 \%$ of the cell mass. When the acetone in the medium was depleted, the PHB content of the cells decreased rapidly. When acetone was supplied in excess so that a concentration of $5 \mathrm{mM}$ remained after $180 \mathrm{~h}$, the PHB content of the cells remained high.

Strain $\mathrm{L} 1$ required $\mathrm{CO}_{2}$ for growth on acetone. No growth occurred in phosphate-buffered medium in the absence of $\mathrm{CO}_{2}$. However, if acetoacetate was supplied as a carbon source, strain $\mathrm{L} 1$ grew in the absence of $\mathrm{CO}_{2}$. Acetoacetate was an intermediate of acetone degradation and was excreted into the medium during growth on nitrate and acetone- $\mathrm{CO}_{2}(0.1$ or $0.24 \mathrm{mM}$ acetoacetone in the presence of 10 or $20 \mathrm{mM}$ acetone, respectively). After depletion of acetone, acetoacetate was reutilized. The electron balance for growth of strain L1 on nitrate-acetone- $\mathrm{CO}_{2}$ was 95 to $98 \%$ (Table 1). Acetone and nitrate were consumed by cells, and $\mathrm{CO}_{2}$ (not quantified in this experiment), $\mathrm{N}_{2}$, and $\mathrm{PHB}$ were formed. The nitrate/nitrogen ratio was 0.95 , indicating a nearly quantitative denitrification. Nitrite could not be detected in the cultures. Cells contained about $25 \%(\mathrm{wt} / \mathrm{wt})$ PHB. Following growth with $\left[2-{ }^{14} \mathrm{C}\right] \mathrm{ac}-$

TABLE 1. Product recovery during anoxic growth of strain $\mathrm{L} 1$ in medium with acetone and nitrate ${ }^{a}$

\begin{tabular}{lc}
\hline \multicolumn{1}{c}{ Substrate or product } & $\begin{array}{c}\text { mol consumed or produced/mol } \\
\text { of acetone consumed }\end{array}$ \\
\hline Nitrate & $1.92 \pm 0.22^{b}$ \\
$\mathrm{~N}_{2}$ & $1.85 \pm 0.32$ \\
${\text { Cell mass, including } \mathrm{PHB}^{c}}_{\text {PHB }^{d}}$ & $0.31 \pm 0.071$ \\
Recovery $^{e}$ & $0.087 \pm 0.042$ \\
\hline
\end{tabular}

${ }^{a}$ Strain L1 was grown in $80 \mathrm{ml}$ of carbonate-buffered mineral medium containing $30 \mathrm{mM}$ nitrate and $10 \mathrm{mM}$ acetone. Cells were harvested in the exponential growth phase.

${ }^{b}$ Results are the averages of the data of three cultures \pm the standard deviations.

${ }^{c}$ Molecular mass of average cell composition $\left(\mathrm{C}_{4} \mathrm{H}_{7} \mathrm{O}_{3}\right), 103 \mathrm{~g} / \mathrm{mol}$

${ }^{d}$ Molecular mass of hydroxybutyrate in PHB $\left(\mathrm{C}_{4} \mathrm{H}_{6} \mathrm{O}_{2}\right), 86 \mathrm{~g} / \mathrm{mol}$.

e The recovery of acetone converted to $\mathrm{CO}_{2}$, cell mass, or PHB was calculated from the following reactions (according to Platen and Schink [36]):

$5 \mathrm{C}_{3} \mathrm{H}_{6} \mathrm{O}+16 \mathrm{NO}_{3}{ }^{-}+16 \mathrm{H}^{+} \rightarrow 15 \mathrm{CO}_{2}+8 \mathrm{~N}_{2}+23 \mathrm{H}_{2} \mathrm{O}$ (oxidation of acetone) $17 \mathrm{C}_{3} \mathrm{H}_{6} \mathrm{C} \mathrm{H}_{6} \mathrm{O}+5 \mathrm{CO}_{2} \rightarrow 8 \mathrm{C}_{4} \mathrm{H}_{6} \mathrm{O}_{2}+3 \mathrm{H}_{2} \mathrm{O}$ (formation of PHB) 


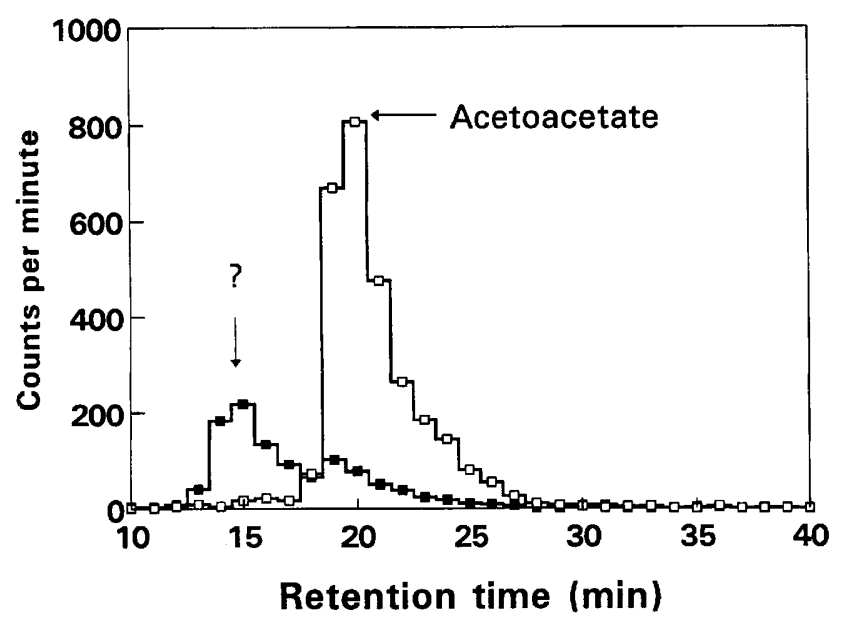

FIG. 4. Formation of $\left[{ }^{14} \mathrm{C}\right]$ acetoacetate from $\left[2-{ }^{14} \mathrm{C}\right]$ acetone or $\mathrm{NaH}^{14} \mathrm{CO}_{3}$ by strain L1. Strain L1 was grown anaerobically to an OD of 0.8 in $20 \mathrm{ml}$ of carbonate-buffered mineral medium that contained $30 \mathrm{mM}$ nitrate and $10 \mathrm{mM}$ acetone. Then $10 \mathrm{mM}$ acetone and either $50 \mathrm{mM} \mathrm{NaH}{ }^{14} \mathrm{CO}_{3}(0.96 \mu \mathrm{Ci} / \mathrm{mmol})$ (घ) or $\left[2-{ }^{14} \mathrm{C}\right]$ acetone $(0.112 \mu \mathrm{Ci} / \mathrm{mmol})(\square)$ was supplemented. The incubation was continued for $80 \mathrm{~h}$. Radioactivity of fractions obtained by HPLC separation of cell-free culture supernatant was recorded.

etone, 10.1 to $13.6 \%$ of the radiolabel was incorporated into the cells (mainly in PHB), but most of the radiolabel was released as ${ }^{14} \mathrm{CO}_{2}$ (85 to $\left.88 \%\right)$. Some acetoacetate and a small amount of an unidentified compound were also formed from $\left[2-{ }^{14}\right.$ C] acetone or ${ }^{14} \mathrm{CO}_{2}$ (Fig. 4).

Enzyme activities for the degradation of acetone and 2-propanol. Extracts of cells grown with either acetone or 2-propanol contained all the enzymes of the acetoacetate pathway for the degradation of acetone (Table 2).

Phylogenetic relationships of strain L1. The $16 \mathrm{~S}$ rDNA sequence of strain L1 had 96 to $97 \%$ similarity to that of Paracoccus kocurii, Paracoccus alcaliphilus, Paracoccus aminophilus, Paracoccus denitrificans, Paracoccus aminovorans, and

TABLE 2. Enzymes of the acetoacetate pathway following growth of strain L1 on either acetone or 2-propanol ${ }^{a}$

\begin{tabular}{lcc}
\hline & \multicolumn{2}{c}{$\begin{array}{c}\text { Sp act (U/mg of protein) } \\
\text { following growth on: }\end{array}$} \\
\cline { 2 - 3 } \multicolumn{1}{c}{ Enzyme } & Acetone & 2-Propanol \\
\hline 2-Propanol:NAD ${ }^{+}$oxidoreductase & $<0.010$ & $<0.010$ \\
2-Propanol:NADP ${ }^{+}$oxidoreductase & $<0.010$ & $\mathrm{ND}^{b}$ \\
3-Hydroxybutyrate:NAD ${ }^{+}$oxidoreductase & 0.307 & 0.288 \\
3-Hydroxybutyrate:NADP ${ }^{+}$oxidoreductase & 0.028 & $\mathrm{ND}$ \\
3-Hydroxyacyl-CoA:NAD ${ }^{+}$oxidoreductase & 0.438 & 0.431 \\
3-Hydroxyacyl-CoA:NADP ${ }^{+}$oxidoreductase & 0.011 & $\mathrm{ND}$ \\
Malate:NAD ${ }^{+}$oxidoreductase & 1.850 & 1.454 \\
Malate:NADP ${ }^{+}$oxidoreductase & 0.291 & $\mathrm{ND}$ \\
Thiolase & 1.321 & 0.522 \\
Succinyl-CoA:acetoacetate CoA transferase & $0.763^{c}$ & 0.748 \\
Malate synthase & 0.195 & 0.090 \\
Isocitrate lyase & $<0.010$ & $<0.010$ \\
\hline
\end{tabular}

${ }^{a}$ Strain $\mathbf{L} 1$ was grown in carbonate-buffered medium with $30 \mathrm{mM}$ nitrate and $10 \mathrm{mM}$ acetone or $10 \mathrm{mM}$ 2-propanol. Cells were harvested in the exponential growth phase. As a source of enzymes, cell extracts were prepared by ultrasonication and centrifugation. Enzyme activities were determined at $30^{\circ} \mathrm{C}$.

${ }^{b} \mathrm{ND}$, not determined.

c The specific activity was $2.5 \mathrm{U} / \mathrm{mg}$ in cells of the stationary growth phase. All other enzyme activities were not increased.

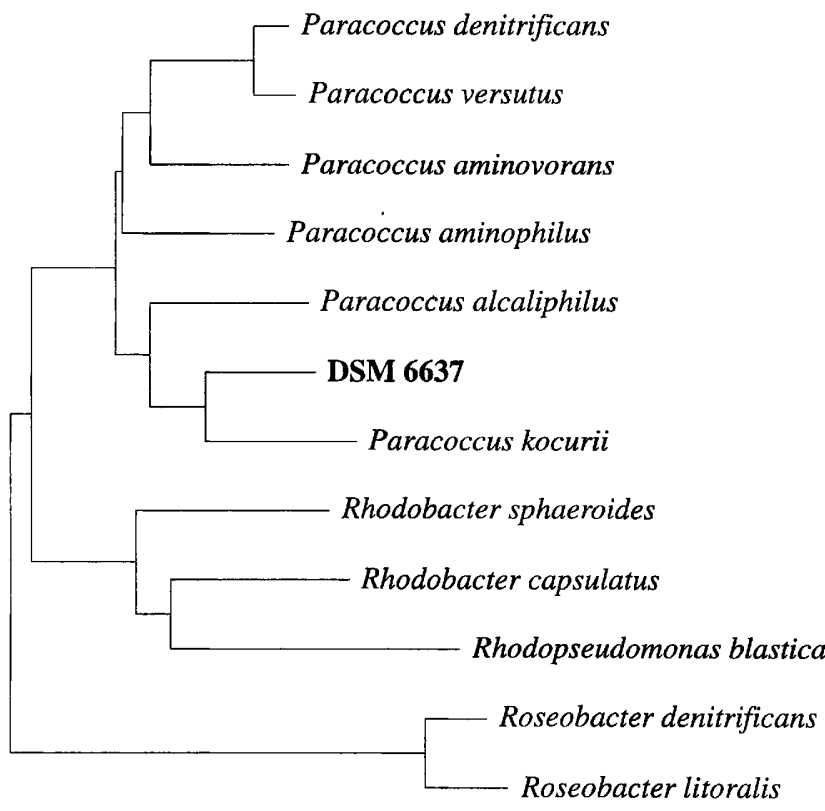

$5 \%$

FIG. 5. Dendrogram showing the relatedness of strain L1 to different Paracoccus species. Strain alignment in the dendrogram was performed as described in Materials and Methods. The bar at the bottom represents percent sequence similarity.

Paracoccus versutus. Phylogenetic analysis suggested that strain L1 was a distinct species within the genus Paracoccus (Fig. 5).

Comparison of the protein pattern of strain $L 1$ with that of $T$. pantotropha. Since neither strain $\mathrm{L} 1$ nor $T$. pantotropha contained DAP as a diamino acid in their cell walls, the protein patterns of the two organisms were compared (Fig. 6). The protein patterns in the polyacrylamide gels did not indicate similarities between the two Paracoccus species.

G $+C$ content of DNA and DNA-DNA similarity. The $G+C$ content of the DNA of strain L1 was $68.5 \mathrm{~mol} \%$ (by HPLC analysis) or $70 \mathrm{~mol} \%$ (by the $\mathrm{T}_{\mathrm{m}}$ method). The $\mathrm{G}+\mathrm{C}$ content of T. pantotropha DNA was 65.8 to $66 \mathrm{~mol} \%$ (42), and that of P. kocurii was $71 \mathrm{~mol} \%$ (32). Hybridization of the DNAs of strain $\mathrm{L} 1$ and $T$. pantotropha revealed only 18 to $23 \%$ similarity, which indicated that they are not closely related.

\section{DISCUSSION}

Acetone degradation by microorganisms was possible under aerobic $(25,28,44,48)$ or strictly anaerobic growth conditions, in association with either methanogenesis (35) or sulfate reduction $(38,52)$. Acetone could also be degraded under anoxic conditions in the presence of nitrate $(36,37,42)$. Aerobic degradation of acetone was reported to proceed via acetol or 1,2-propanediol formation $(46,48)$, whereas anaerobic degradation by $T$. pantotropha (6), Desulfococcus biacutus (38), or a gram-negative denitrifying strain, $\operatorname{BunN}(18,36)$, proceeded via carboxylation to acetoacetate. The latter pathway is presumably used by strain $\mathrm{L} 1$, since no growth was observed with acetone in the absence of bicarbonate or $\mathrm{CO}_{2}$ whereas cultures grew with acetoacetate in the absence of $\mathrm{CO}_{2}$. Acetone was degraded to $\mathrm{CO}_{2}$, utilized for biosynthesis of $\mathrm{PHB}$, or excreted as acetoacetate. The molar growth yield on acetone- $\mathrm{CO}_{2}$-nitrate and acetoacetate-nitrate was 27 to $28 \mathrm{~g} / \mathrm{mol}$ and was in 


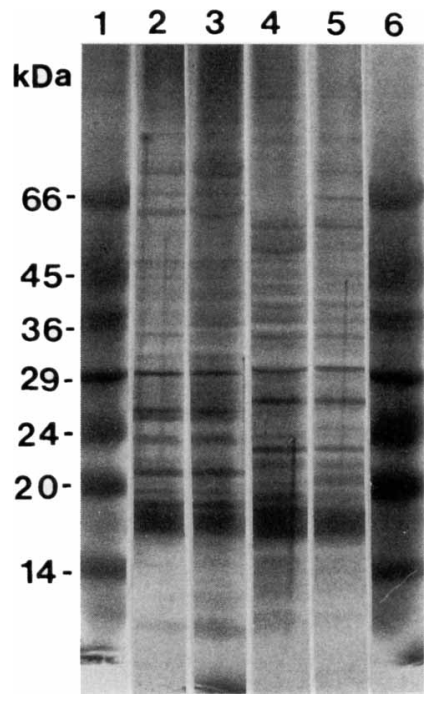

FIG. 6. SDS-polyacrylamide gel electrophoresis of crude extracts of isolate L1 and T. pantotropha. Lanes 1 and 6, standard proteins; lanes 2 and 3, crude extracts of isolate L1 grown on acetone and butanone, respectively; lanes 4 and 5 , crude extracts of $T$. pantotropha grown on acetone and glucose, respectively. Cells were grown in standard medium containing $10 \mathrm{mM}$ acetone, butanone, or glucose in the presence of $40 \mathrm{mM}$ nitrate under an $\mathrm{N}_{2}-\mathrm{CO}_{2}(80: 20$ [vol/vol]) gas phase.

the same range as that reported for the gram-negative denitrifying strain BunN (36), whereas the sulfate-reducing strain KMRActS (37) had a much lower growth yield and longer doubling times. No nitrite was excreted by strain L1, as was similarly observed for strain BunN (36).

During growth of strain $\mathrm{L} 1$ on $\left[2-{ }^{14} \mathrm{C}\right]$ acetone- $\mathrm{CO}_{2}$ with an excess of nitrate, up to $40 \%$ of the cell dry weight was PHB. The PHB content was variable. When acetone and ${ }^{14} \mathrm{CO}_{2}$ were supplied as carbon sources for strain $\mathrm{L} 1$, some ${ }^{14} \mathrm{C}$ was incorporated into PHB during early log phase (OD, $\leq 0.4)$. Dense cell suspensions of strain BunN (36) and D. biacutus (38), by comparison, incorporated ${ }^{14} \mathrm{CO}_{2}$ in the same order of magnitude, mainly as PHB.

Like other gram-negative or gram-variable Proteobacteria, strain L1 degraded acetone via acetoacetate, whereas grampositive acetone-utilizing soil organisms, presumably of the Corynebacterium group (46) and Bacillus spp. as well as Mycobacterium spp. $(16,27,48)$, used the 1,2-propanediol and acetol pathway.

Since $T$. pantotropha tended to react gram variable in some of our preparations, did not contain DAP in its cell wall murein (which is exceptional for gram-negative bacteria), was easily lysed with lysozyme, and had a $\mathrm{G}+\mathrm{C}$ content close to that of strain L1, DNA-DNA hybridization was performed. The results indicated that the two organisms are not closely related, as was also obvious from the cytoplasmic-protein patterns. The work of Ludwig et al. (26) classified T. pantotropha as Paracoccus denitrificans. In contrast, Goodhew et al. (16) recently suggested reclassification of $T$. pantotropha as Paracoccus pantotropha, together with $P$. denitrificans LMD 5244, whereas other $P$. denitrificans strains formed a distinct group. Although the cell wall structures of hydrogen bacteria, including $P$. denitrificans, were compared (50), no chemical composition reflecting the presence of DAP has been determined.

Whereas $T$. pantotropha and the denitrifying gram-negative strain BunN described by Platen and Schink (36) utilized several sugars and many alcohols, ketones, and fatty acids, strain
L1 used only ribose, gluconate, and a few alcohols, ketones, and fatty acids. It could utilize 5 of 16 tested amino acids, but it could not use methylamines, the typical substrate of $P$. kocurii (32).

Thus, strain L1 was significantly different from other acetone-degrading bacteria. Strain L1 clustered within the paracoccus group of the alpha subclass of the Proteobacteria in the vicinity of $P$. kocurii (Fig. 5). However, the most closely related Paracoccus strains have a very distinct spectrum of substrates. The DNA-DNA similarity to T. pantotropha is less than $70 \%$. Thus, strain L1 is considered to represent a new species, Paracoccus solventivorans $\mathrm{sp}$. nov.

Description of Paracoccus solventivorans sp. nov. Paracoccus solventivorans (sol.ven.ti.vo'.rans, M. L. neut. n. solventum, solvent; L. part. pres. vorans, eating; M. L. solventivorans, solvent eating). This organism has a gram-negative cell wall architecture, but the gram stain reaction is variable. Cells are coccoid or rodlike, 0.4 to 0.5 by 0.9 to $1.5 \mu \mathrm{m}$. The bacterium is non-spore forming and nonmotile. Light-scattering PHB inclusions are evident. The murein lacks DAP. The optimum growth temperature is 30 to $37^{\circ} \mathrm{C}$; the optimum $\mathrm{pH}$ is 7 to 8 . $\mathrm{NaCl}$ is inhibitory at concentrations $>0.2 \%$. No vitamin addition is required.

The electron acceptors are oxygen and nitrate. $\mathrm{N}_{2}$ is produced from nitrate via respiration. Acetone is oxidized to $\mathrm{CO}_{2}$ and metabolized to PHB. Besides acetone, 2-butanone, 2-propanol, fumarate, succinate, gluconate, glutamate, aspartate, asparagine, $\alpha$-ketoglutarate, isoleucine, glycine, ribose, propionate, $n$-butyrate, 3 -hydroxybutyrate, acetoacetate, Casamino Acids, gluconate, and pyruvate could serve as carbon sources. Many other substances are not utilized. Acetone is degraded via acetoacetate. The $\mathrm{G}+\mathrm{C}$ content of the DNA is $68.5 \mathrm{~mol} \%$ (as determined by HPLC) or $70 \mathrm{~mol} \%$ (as determined by $\mathrm{T}_{\mathrm{m}}$ ). This organism is a member of the alpha subgroup of proteobacteria (paracocci group) according to the results of phylogenetic analysis. It has been deposited with Deutsche Sammlung von Mikroorganismen und Zellkulturen under accession number DSM 6637.

Nucleotide sequence accession number. The sequence of the gene coding for the 16S rRNA has been deposited in the EMBL under the accession number Y07705.

\section{ACKNOWLEDGMENTS}

This work was supported by the Deutsche Forschungsgemeinschaft.

We thank H. G. Heumann for preparing the electron photomicrographs of thin sections of strain L1 and R. Morenweiser for performing enrichment and isolation procedures.

\section{REFERENCES}

1. Anderson, A. J., and E. A. Dawes. 1990. Occurrence, metabolism, metabolic role, and industrial uses of bacterial polyhydroxyalkanoates. Microbiol. Rev. 54:450-475.

2. Balch, W. E., G. E. Fox, J. L. Magrum, C. R. Woese, and R. S. Wolfe. 1979 Methanogens: reevaluation of a unique biological group. Microbiol. Rev. 43:260-296.

3. Bergmeyer, H. U. 1983. Methoden der enzymatischen Analyse, 3rd ed., vol. I to III. Verlag Chemie, Weinheim, Germany.

4. Birnstiel, M. L., B. H. Sells, and I. F. Purdom. 1972. Kinetic properties of RNA molecules. J. Mol. Biol. 63:21-39.

5. Bleicher, K., G. Zellner, and J. Winter. 1989. Growth of methanogens on cyclopentanol/ $\mathrm{CO}_{2}$ and specificity of alcohol dehydrogenase. FEMS Microbiol. Lett. 59:307-312.

6. Bonnet-Smits, E. M., L. A. Robertson, J. A. vanDijken, E. Senior, and J. G. Kuenen. 1988. Carbon dioxide fixation as the initial step in the metabolism of acetone by Thiosphaera pantotropha. J. Gen. Microbiol. 134:2281-2289.

7. Bradford, M. M. 1976. A rapid and sensitive method for quantitation of microgram quantities of protein utilizing the principle of protein-dye binding. Anal. Biochem. 72:248-254.

8. Bray, G. A. 1960. A simple efficient liquid scintillator for counting aqueous solutions in a liquid scintillation counter. Anal. Biochem. 1:279-285. 
9. De Soete, G. 1983. A least square algorithm for fitting additive trees to proximity data. Psychometrika 48:621-626.

9a.Deutsche Sammlung von Mikroorganismen und Zellkulturen. 1989. Catalogue of strains. Deutsche Sammlung von Mikroorganismen und Zellkulturen $\mathrm{GmbH}$, Braunschweig, Germany.

10. Dixon, G. H., and H. L. Kornberg. 1959. Assay methods for key enzymes of the glyoxylate cycle. Biochem. J. 72:3P.

11. Doi, Y., M. Kunioka, Y. Nakamura, and K. Soga. 1986. Nuclear magnetic resonance studies on poly- $\beta$-hydroxybutyrate and a copolyester of poly- $\beta$ hydroxybutyrate and $\beta$-hydroxyvalerate, isolated from Alcaligenes eutrophus H16. Macromolecules 19:2860-2864.

12. Drews, G. 1983. Mikrobiologisches Praktikum, 4th ed. Springer-Verlag, Berlin.

13. Fachgruppe Wasserchemie GDCh. 1981. Deutsche Einheitsverfahren zur Wasser-, Abwasser- und Schlammuntersuchung, 10th contribution. Verlag Chemie, Weinheim, Germany.

14. Gillespie, S., and D. Gillespie. 1971. Ribonucleic acid-deoxyribonucleic acid hybridization in aqueous solutions and in solutions containing formamide. Biochem. J. 125:481-487.

15. Goepfert, G. J. 1943. Studies on the mechanism of dehydrogenation by Fusarium lini Bolley. XIX. Dehydrogenation of higher primary and secondary alcohols. J. Biol. Chem. 140:525-534.

16. Goodhew, C. E., G. W. Pettigrew, B. Devreese, J. Van Beeumen, R. J. M. Van Spanning, S. C. Baker, N. Saunders, S. J. Ferguson, and I. P. Thompson. 1996. The cytochromes c-550 of Paracoccus denitrificans and Thiosphaera pantotropha: a need for re-evaluation of the history of Paracoccus cultures. FEMS Microbiol. Lett. 137:95-101.

17. Hempelman, E. 1982. Bilden und Auflösen von Proteinstapeln, p. 111-116. In B. J. Radola (ed.), Elektrophorese Forum. Walter de Gruyter, Berlin.

18. Janssen, P. H., and B. Schink. $1995 .{ }^{14} \mathrm{CO}_{2}$ exchange with acetoacetate catalyzed by dialysed cell-free extracts of the bacteria strain BunN grown with acetone and nitrate. Eur. J. Biochem. 228:677-682.

19. Jukes, T. H., and C. R. Cantor. 1969. Evolution of protein molecules, p. 211-232. In H. N. Munro (ed.), Mamalian protein metabolism. Academic Press, New York.

20. Karr, D. B., J. K. Waters, and D. W. Emerich. 1983. Analysis of poly- $\beta$ hydroxybutyrate in Rhizobium japonicum bacteroids by ion-exclusion highpressure liquid chromatography and UV detection. Appl. Environ. Microbiol. 46:1339-1344.

21. Kelly, R. B., N. R. Cozzarelli, M. B. Deutscher, J. R. Lehmann, and A Kornberg. 1970. Enzymatic synthesis of DNA. XXXII. Replication of duplex deoxyribonucleic acid by polymerase at a single strand break. J. Biol. Chem. 245:39-45.

2.2. Kretzer, A., and J. R. Andreesen. 1991. A new pathway for isonicotinate degradation by Mycobacterium sp. INA I. J. Gen. Microbiol. 137:1073-1080.

23. Laemmli, U. K. 1970. Cleavage of structural proteins during the assembly of the head of bacteriophage T4. Nature (London) 227:680-685.

24. Law, J. H., and R. A. Slepecky. 1961. Assay of poly- $\beta$-hydroxybutyric acid. J. Bacteriol. 82:33-36.

25. Levine, S., and L. O. Krampitz. 1952. The oxidation of acetone by a soil diphtheroid. J. Bacteriol. 64:645-650.

26. Ludwig, W., G. Mittenhuber, and C. G. Friedrich. 1993. Transfer of Thiosphaera pantotropha to Paracoccus denitrificans. Int. J. Syst. Bacteriol. 43: 363-367.

27. Lukins, H. B., and J. W. Foster. 1963. Methyl ketone metabolism in hydrocarbon-utilizing mycobacteria. J. Bacteriol. 85:1074-1087.

28. Madigan, M. T. 1990. Photocatabolism of acetone by nonsulfur purple bacteria. FEMS Microbiol. Lett. 71:281-286.

29. Maidak, B. L., N. Larsen, M. J. McCaughey, R. Overbeek, G. J. Olsen, K. Fogel, J. Blandy, and C. R. Woese. 1994. The ribosomal data base project. Nucleic Acids Res. 22:3485-3487.

30. Marmur, J., and P. Doty. 1962. Determination of the base composition of desoxyribonucleic acid from its thermal denaturation temperature. J. Mol. Biol. 5:109-118.

30a.Merck \& Co., Inc. 1976. The Merck index-an encyclopedia of chemicals and drugs. Merck \& Co., Inc., Rahway, N.J.

31. Mirault, M. E., and K. Scherer. 1971. Isolation of preribosome from $\mathrm{HeLa}$ cells and its characterization by electrophoresis on uniform and exponential gradient polyacrylamide gels. Eur. J. Biochem. 23:372-384.

32. Ohara, M., Y. Katayama, M. Tsuzaki, S. Nakamoto, and H. Kuraishi. 1990.
Paracoccus kocurii sp. nov., a tetramethylammonium-assimilating bacterium. Int. J. Syst. Bacteriol. 40:292-296.

33. Ostle, A. G., and J. G. Holt. 1982. Nile blue A as a fluorescent stain for poly- $\beta$-hydroxybutyrate. Appl. Environ. Microbiol. 44:238-241.

34. Pfennig, N., and S. Wagener. 1986. An improved method of preparing wet mounts for photomicrographs of microorganisms. J. Microbiol. Methods 4:303-306.

35. Platen, H., and B. Schink. 1987. Methanogenic degradation of acetone by an enrichment culture. Arch. Microbiol. 149:136-141.

36. Platen, H., and B. Schink. 1989. Anaerobic degradation of acetone and higher ketones via carboxylation by newly isolated denitrifying bacteria. J. Gen. Microbiol. 135:883-891.

37. Platen, H., and B. Schink. 1990. Enzymes involved in anaerobic degradation of acetone by a denitrifying bacterium. Biodegradation 1:243-251.

38. Platen, H., A. Temmes, and B. Schink. 1990. Anaerobic degradation of acetone by Desulfococcus biacutus sp. nov. Arch. Microbiol. 154:355-361.

39. Rainey, F. A., M. Dorsch, H. W. Morgan, and E. Stackebrandt. 1992. 16S rDNA analysis of Spirochaeta thermophila: position and implications for the systematics of the order Spirochaetales. Syst. Appl. Microbiol. 16:224-226.

40. Rainey, F. A., and E. Stackebrandt. 1993. 16S rDNA analysis reveals phylogenetic diversity among the polysaccharolytic clostridia. FEMS Microbiol. Lett. 113:125-128.

41. Rhuland, L. E., E. Work, R. E. Denman, and D. S. Hoare. 1955. The behaviour of the isomers of $\alpha, \varepsilon$-diaminopimelic acid on paper chromatograms. J. Am. Soc. 77:4844-4846.

42. Robertson, L. A., and J. G. Kuenen. 1983. Thiosphaera pantotropha gen. nov., sp. nov., a facultatively anaerobic, facultatively autotrophic sulfur bacterium. J. Gen. Microbiol, 129:2847-2855.

43. Schlegel, H. G. 1992. Allgemeine Mikrobiologie, 7th ed., p. 316-321. Georg Thieme Verlag, Stuttgart.

44. Siegel, J. M. 1950. The metabolism of acetone by the photosynthetic bacterium Rhodopseudomonas gelatinosa. J. Bacteriol. 60:595-606.

45. Stern, J. R. 1956. Optical properties of acetoacetate-S-coenzyme and its metal chelates. J. Biol. Chem. 218:971-983.

46. Taylor, D. G., P. W. Trudgill, R. E. Cripps, and P. R. Harris. 1980. The microbial metabolism of acetone. J. Gen. Microbiol. 118:159-170.

47. Tschech, A., and N. Pfennig. 1984. Growth yield increase linked to caffeate reduction in Acetobacterium woodii. Arch. Microbiol. 137:163-167.

48. Vestal, J. R., and J. J. Perry. 1969. Divergent metabolic pathways for propane and propionate utilization by a soil isolate. J. Bacteriol. 99:216-221.

49. Walker, P. G. 1954. A colorimetric method for the estimation of acetoacetate. Biochem. J. 58:699-704.

50. Walther-Mauruschat, A., M. Aragno, F. Mayer, and H. G. Schlegel. 1977. Micromorphology of gram-negative hydrogen bacteria. Arch. Microbiol. 114: 101-110.

51. Widdel, F. 1986. Growth of methanogenic bacteria in pure culture with 2-propanol and other alcohols as hydrogen donors. Appl. Environ. Microbiol. 51:1056-1062.

52. Widdel, F. 1988. Microbiology and ecology of sulfate- and sulfur-reducing bacteria, p. 469-585. In A. J. B. Zehnder (ed.), Biology of anaerobic microorganisms. John Wiley \& Sons, New York.

53. Widdel, F., G. W. Koehring, and F. Mayer. 1983. Studies on the sulfatereducing bacteria that decompose fatty acids. III. Characterization of the filamentous gliding Desulfonema limicola gen. nov. sp. nov. Arch. Microbiol. 134:284-294.

54. Winter, J., E. Braun, and H.-P. Zabel. 1987. Acetomicrobium faecalis spec. nov., a strictly anaerobic bacterium from sewage sludge, producing ethanol from pentoses. Syst. Appl. Microbiol. 9:71-76.

55. Winter, J., C. Lerp, H.-P. Zabel, F. X. Wildenauer, H. König, and F. Schindler. 1984. Methanobacterium wolfei sp. nov., a new tungsten-requiring, thermophilic, autotrophic methanogen. Syst. Appl. Microbiol. 5:457-466.

56. Wolin, E. A., M. J. Wolin, and R. S. Wolfe. 1963. Formation of methane by bacterial extracts. J. Biol. Chem. 238:2882-2886.

57. Zellner, G., E. Stackebrandt, P. Messner, B. J. Tindall, E. Conway de Macario, H. Kneifel, U. B. Sleytr, and J. Winter. 1989. Methanocorpusculaceae fam. nov., represented by Methanocorpusculum parvum, Methanocorpusculum sinense sp. nov. and Methanocorpusculum bavaricum sp. nov. Arch. Microbiol. 151:381-390.

58. Zellner, G., and J. Winter. 1987. Secondary alcohols as hydrogen donors for $\mathrm{CO}_{2}$ reduction by methanogens. FEMS Microbiol. Lett. 44:323-328. 